University of Puget Sound

Sound Ideas

Fall 2020

\title{
Autonomic Nervous System Changes in Individuals with Anxiety And Depression Across the Lifespan: A Systematic Review
}

\author{
Justin Peterson SPT \\ University of Puget Sound \\ Brandon Funk SPT \\ University of Puget Sound \\ Rachel C. Sannicandro SPT \\ University of Puget Sound \\ Anna K. Ortung SPT \\ University of Puget Sound \\ Karin Steere DPT \\ University of Puget Sound
}

Follow this and additional works at: https://soundideas.pugetsound.edu/ptsymposium

Part of the Physical Therapy Commons

\section{Recommended Citation}

Peterson, Justin SPT; Funk, Brandon SPT; Sannicandro, Rachel C. SPT; Ortung, Anna K. SPT; and Steere, Karin DPT, "Autonomic Nervous System Changes in Individuals with Anxiety And Depression Across the Lifespan: A Systematic Review" (2020). Physical Therapy Research Symposium. 63.

https://soundideas.pugetsound.edu/ptsymposium/63

This Poster is brought to you for free and open access by the Physical Therapy, School of at Sound Ideas. It has been accepted for inclusion in Physical Therapy Research Symposium by an authorized administrator of Sound Ideas. For more information, please contact soundideas@pugetsound.edu. 


\section{AUTONOMIC NERVOUS SYSTEM CHANGES IN INDIVIDUALS WITH ANXIETY AND DEPRESSION ACROSS THE LIFESPAN: A SYSTEMATIC REVIEW}

Steere K, DPT; Funk B, SPT; Ortung A, SPT; Peterson J, SPT; Sannicandro R, SPT School of Physical Therapy, University of Puget Sound, Tacoma, WA,USA

\section{Introduction}

- Heart rate variability (HRV) can be used a measure of systemic health.

- Reduced HRV is correlated to many chronic conditions like cardiovascular disease and chronic pain.

- Evidence suggests psychiatric disorders can have similar systemic effects.

- The two most common disorders, anxiety and depression, are the focus of our review. They also share similar systemic effects.

- Aim: determine the relationship between anxiety and/or depression and HRV across the age spectrum.

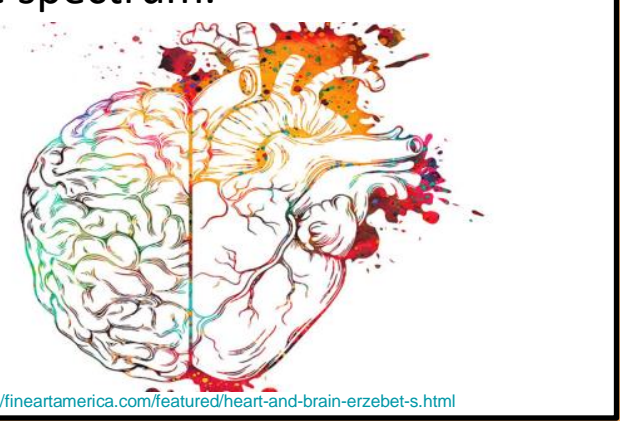

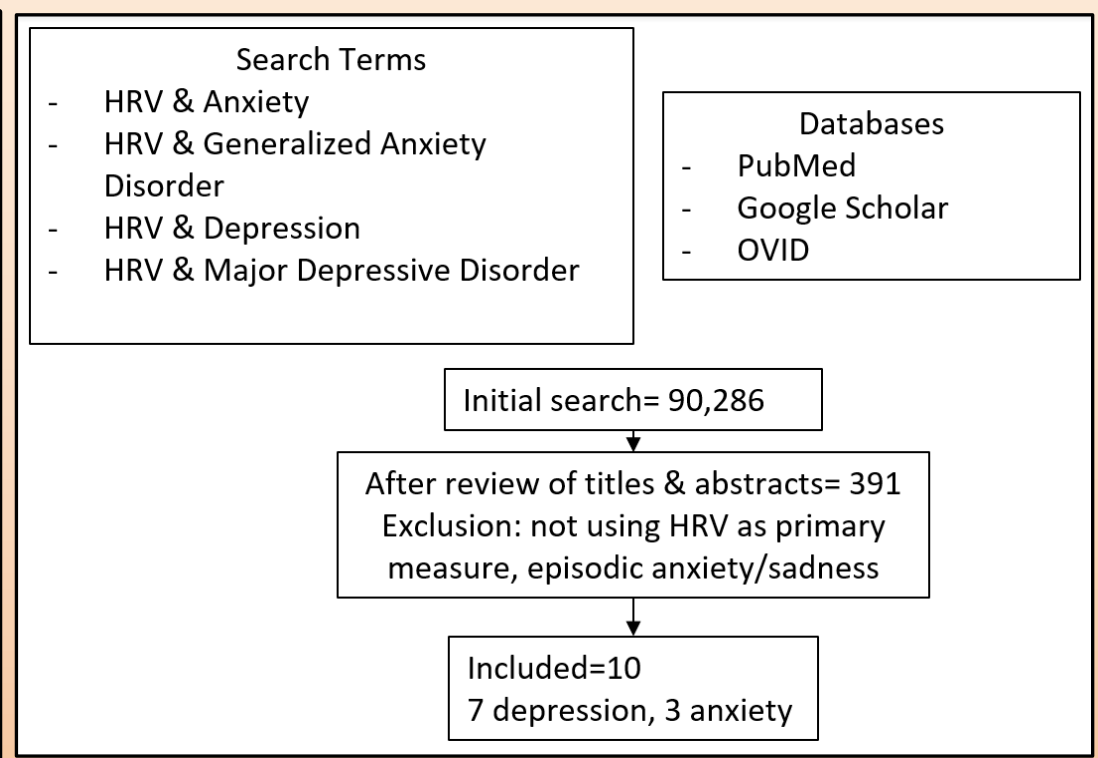

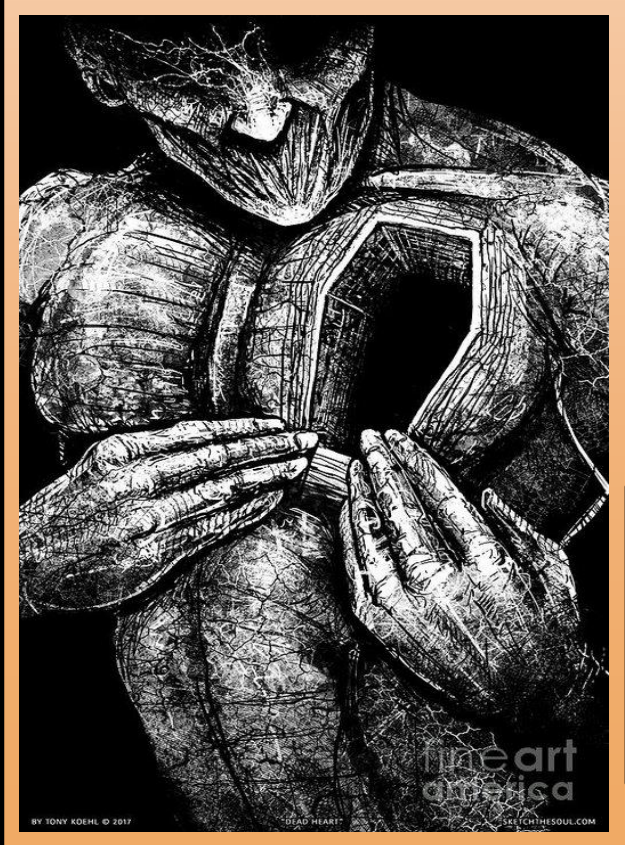

Acknowledgments This research was supported and funded by the University of Puget Sound School of Physical Therapy and SPTA.

References are available on request; contact Karin Steere:

ksteere@pugetsound.edu

\section{$\underline{\text { Results }}$}

- Anxiety and depression correlate to diminished HRV

- Primarily a decrease in high frequency (HF) power, increase in LF:HF ratio, inconsistent decrease in low frequency (LF) power

- Most significant change in individuals with preexisting heart disease and anxiety

\section{Conclusions}

- Psychiatric disorders have a deleterious effect on the autonomic nervous system

- Earlier detection of these systemic changes may allow interventions to be implemented that could reduce risk of further systemic disease.

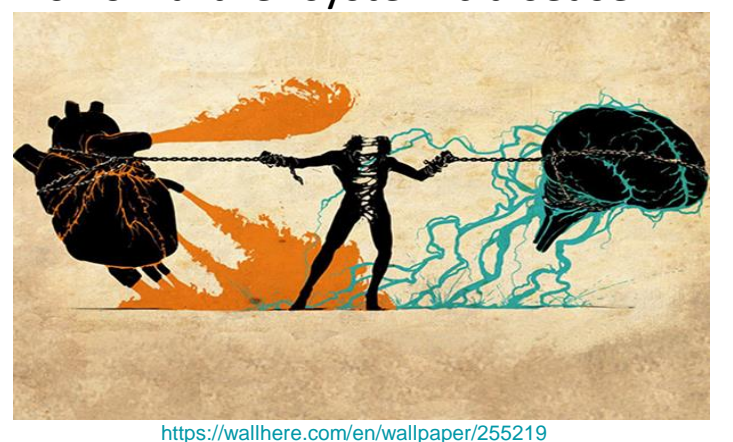

